\author{
PIOTR SOBICZEWSKI \\ Instytut Ogrodnictwa - Państwowy Instytut Badawczy \\ Konstytucji 3 Maja 1/3, 96-100 Skierniewice \\ E-mail: piotr.sobiczewski@inhort.pl
}

\title{
BAKTERIE W ŚRODOWISKU ROŚLIN - WROGOWIE I SPRZYMIERZEŃCY
}

\section{WSTEP}

Mikrobiom środowiska roślin, w skład którego wchodza m.in. bakterie, jest determinowany zarówno pod względem jakościowym, jak i ilościowym warunkami występującymi w danym ekosystemie. Najczęściej dominuja w nim bakterie komensalne, nie majace wykrywalnego wpływu na wzrost roślin czy ich fizjologię. Wśród bakterii mutualistycznych wyróżniaja się mikrosymbionty roślin bobowatych oraz inne bakterie stymulujace wzrost i plonowanie roślin. Działanie tych ostatnich polega na zwiększaniu biodostępności składników pokarmowych, wytwarzaniu substancji polepszajacych wzrost roślin czy ograniczaniu patogenów i innych szkodliwych dla roślin organizmów. Wpływ bakterii na stan zdrowotny i kondycję roślin obejmuje także ich udział w bioremediacji zanieczyszczeń glebowych, dekompozycji materii organicznej i poprawie struktury gleby. Wśród bakterii bytujacych w środowisku roślin na szczególną uwage zasługuja patogeny zarówno roślin, człowieka, jak i zwierząt. Uwzględniajacc aktualne tendencje dotyczace stosowania $\mathrm{w}$ uprawie i ochronie roślin metod przyjaznych środowisku, szczepy niektórych gatunków bakterii sa wykorzystywane także jako czynniki biologicznej ochrony roślin przed chorobami.

\section{PATOGENY ROŚLIN}

Spośród poznanych dotychczas ponad 10000 hodowalnych gatunków bakterii, po- nad 150 powoduje choroby roślin. Wyróżnia się wśród nich bakterie właściwe oraz bakterie, których komórki nie maja ściany komórkowej, ale sa otoczone trójwarstwowa błonac. Do tych ostatnich zalicza się fitoplazmy (poprzednio nazywane organizmami mykoplazmopodobnymi) i spiroplazmy, które można wyizolować $z$ roślin-gospodarzy lub wektorów tych bakterii (owadów) i hodować na pożywce (KAMIŃSKA 2004).

Prawie wszystkie bakterie fitopatogenne rozwijają się w roślinach-gospodarzach jako pasożyty, większość może też przeżywać bez ich zakażenia jako epibionty, a niekiedy także na zamarłych resztkach roślinnych czy w glebie, jako saprotrofy. Rozprzestrzenianie bakterii porażajacych nadziemną część roślin odbywa się m.in. za pośrednictwem wiatru, deszczu, owadów, ptaków i porażonych roślin. Natomiast bakterie porażajace system korzeniowy rozprzestrzeniaja się m.in. z roztworem glebowym czy poprzez faunę zasiedlająca glebę, np. nicienie. Niemała rolę $w$ rozprzestrzenianiu tych patogenow może odgrywać człowiek, np. podczas wykonywania zabiegów uprawowych. Niektóre bakterie moga rozprzestrzeniać się $z$ materiałem rozmnożeniowym, tj. $z$ nasionami, zrazami czy sadzonkami (SOBICZEWSKI i SCHOLLENBERGER 2002, JANSE 2005, KADO 2010). Proces infekcji roślin przez bakterie przebiega w kilku etapach obejmujacych mechanizmy związane $z$ ich adhezja (przyłączeniem) do odpowiedniego miejsca na roślinie, którym moga być naturalne otwory jak aparaty szparkowe, przetchlinki, hydatody, nektarniki, a także

Słowa kluczowe: bakterie pożyteczne, fitopatogeny, kontaminacja, patogeny roślin i człowieka

*Publikację przygotowano w ramach projektu BioSafeFood „Opracowanie technologii produkcji wysokiej jakości, bezpiecznych dla konsumenta owoców $i$ warzyw z zastosowaniem nowych biopreparatów w ochronie upraw przed chorobam współfinansowanego przez Unię Europejska z Europejskiego Funduszu Rozwoju Regionalnego w ramach Programu Operacyjnego Inteligentny Rozwój 2014-2020. Projekt realizowany w ramach konkursu Narodowego Centrum Badań i Rozwoju: 4.1.2 Regionalne Agendy Naukowo Badawcze, nr projektu POIR.04.01.02-00-0100/17-00. 
Tabela 1. Przykłady bakteryjnych patogenów roślin i powodowanych przez nie chorób.

\begin{tabular}{|c|c|c|c|c|c|}
\hline $\begin{array}{l}\text { Nekrogen (nekrozy } \\
\text { zgorzele, zrakowa- } \\
\text { cenia) }\end{array}$ & Choroba & $\begin{array}{l}\text { Macerogen } \\
\text { (miękkie, mokre } \\
\text { zgnilizny) }\end{array}$ & Choroba & $\begin{array}{l}\text { Onkogen (Tumory, } \\
\text { narośla) }\end{array}$ & Choroba \\
\hline Erwinia amylovora & Zaraza ogniowa & $\begin{array}{l}\text { Pectobacterium ca- } \\
\text { rotovorum subsp. } \\
\text { carotovorum }\end{array}$ & $\begin{array}{l}\text { Mokra zgni- } \\
\text { lizna }\end{array}$ & $\begin{array}{l}\text { Agrobacterium tu- } \\
\text { mefaciens }\end{array}$ & $\begin{array}{l}\text { Guzowatość ko- } \\
\text { rzeni }\end{array}$ \\
\hline $\begin{array}{l}\text { Pseudomonas sy- } \\
\text { ringae pv. syringae }\end{array}$ & $\begin{array}{l}\text { Rak bakteryjny } \\
\text { drzew owoco- } \\
\text { wych }\end{array}$ & $\begin{array}{l}\text { Pseudomonas sy- } \\
\text { ringae pv. macu- } \\
\text { licola }\end{array}$ & $\begin{array}{l}\text { Gnicie róż ka- } \\
\text { lafiora }\end{array}$ & $\begin{array}{l}\text { Agrobacterium rhi- } \\
\text { zogenes }\end{array}$ & $\begin{array}{l}\text { Włosowatość ko- } \\
\text { rzeni }\end{array}$ \\
\hline $\begin{array}{l}\text { Xanthomonas } \\
\text { arboricola pv. ju- } \\
\text { glandis }\end{array}$ & $\begin{array}{l}\text { Bakteryjna zgo- } \\
\text { rzel orzecha } \\
\text { włoskiego }\end{array}$ & $\begin{array}{l}\text { Burkholderia ce- } \\
\text { pacia }\end{array}$ & $\begin{array}{l}\text { Bakterioza ce- } \\
\text { buli }\end{array}$ & $\begin{array}{l}\text { Rhodococcus fa- } \\
\text { scians }\end{array}$ & $\begin{array}{l}\text { Proliferacja pę- } \\
\text { dów chryzantemy }\end{array}$ \\
\hline $\begin{array}{l}\text { Pseudomonas sy- } \\
\text { ringae pv. tomato }\end{array}$ & $\begin{array}{l}\text { Bakteryjna cęt- } \\
\text { kowatość pomi- } \\
\text { dora }\end{array}$ & $\begin{array}{l}\text { Xanthomonas hy- } \\
\text { acinthi }\end{array}$ & $\begin{array}{l}\text { Żółta bakterio- } \\
\text { za hiacynta }\end{array}$ & $\begin{array}{l}\text { Pseudomonas sa- } \\
\text { vastanoi pv. sava- } \\
\text { stanoi }\end{array}$ & $\begin{array}{l}\text { Rak bakteryjny } \\
\text { oliwki }\end{array}$ \\
\hline
\end{tabular}

różnego pochodzenia uszkodzenia, np. spowodowane żerowaniem szkodników, wystąpieniem gradu czy też przez inne czynniki. Po połaczeniu $z$ roślina $i$ adaptacji metabolizmu do nowych warunków, bakterie rozmnażają się i wytwarzają różne związki i czynniki wirulencji, takie jak toksyny, enzymy czy hormony roślinne. Etap ten, nazywany inkubacją, kończy się $z$ powstaniem objawów chorobowych. Wiele bakterii rodzaju Pseudomonas wytwarza toksyny, np. koronatynę czy syringomycynę, indukujace odpowiednio powstawanie chloroz i nekroz. Bakterie powodujące miękkie zgnilizny wytwarzaja szeroki zakres enzymów rozkładajacych ścianę komórek roślinnych. Sa to m.in. pektynazy, celulazy, proteazy czy ksylanazy. Ważnym czynnikiem wirulencji bakterii sa egzopolisacharydy (EPS). Wskutek zatykania wiazek przewodzacych odpowiadaja one m.in. za więdnięcie roślin (JANSE 2005, KADO 2010). Przykładem może być amyloworan wytwarzany przez sprawcę zarazy ogniowej, bakterie Erwinia amylovora. Do czynników odgrywających rolę w patogenności bakterii zalicza się również lipopolisacharydy aktywujace w porażonych roślinach synteze białek zwiazanych $z$ patogeneza, takich jak glukanazy. Wiele bakterii produkuje siderofory chroniace je przed reakcjami obronnymi roślin na zakażenie, m.in. dzięki interakcji $z$ $\mathrm{H}_{2} \mathrm{O}_{2}$ i hamowaniu wytwarzania reaktywnych form tlenu przez rośliny (AGRIOS 2005). Niektóre bakterie zasiedlajace ten sam biotop, moga $\mathrm{w}$ procesie koniugacji wymieniać między soba materiał genetyczny, tzn. przekazywać z komórki dawcy do komórki biorcy część chromosomu czy plazmidy (horyzon- talny transfer genów). Udokumentowane sa m.in. przypadki nabycia zdolności chorobotwórczych przez niepatogenne bakterie rodzaju Agrobacterium czy oporności bakterii rodzajów Pseudomonas i Erwinia na antybiotyki i zwiazki miedzi.

Objawy chorób roślin powodowanych przez bakterie to głównie nekrozy, zgorzele i zrakowacenia, więdnięcia, miękkie (mokre) zgnilizny i narośla. Ze względu na rodzaj powodowanych chorób, bakterie fitopatogenne można podzielić na nekrogeny, macerogeny i onkogeny (BILLING 1987) (Tabela 1). Zakres roślin-gospodarzy poszczególnych patogenów bakteryjnych może być różny: od bardzo szerokiego, obejmujacego nawet kilkaset gatunków roślin, np. Agrobacterium tumefaciens, do bardzo waskiego, np. Xanthomonas fragariae - patogenu porażajacego tylko truskawkę (SOBICZEWSKI i SCHOLLENBERGER 2002). W obrębie niektórych gatunków bakterii wyróżnia się patowary, czyli warianty różniące się zakresem gospodarza na zakażenie przez dany szczep, oraz biowary wskazujące na zróżnicowanie cech fenotypowych patogenu.

\section{PATOGENY ROŚLIN POWODUJĄEE CHOROBY CZŁOWIEKA}

Wyniki badań prowadzonych szczególnie w ostatnich latach wskazuja, że niektóre bakteryjne patogeny roślin maja zdolność zakażania organizmów spoza królestwa roślin (KIM i współaut. 2020). Przykładem może być gatunek Agrobacterium tumefaciens, sprawca guzowatości korzeni wielu gatunków roślin, a odkryty także jako moż- 
liwy patogen człowieka (PAPHITOU i ROLSTON 2003). Infekcja roślin ma charakter genetyczny i polega na włączeniu do ich genomu fragmentu plazmidu Ti (ang. tumor inducing) zawierajacego geny kodujace wytwarzanie w niezbalansowanej ilości auksyn i cytokinin. W wyniku hipertrofii i hiperplazji komórek tworza się, głównie na korzeniach, guzowate narośla (SoBICZEWSKI 1999). W warunkach eksperymentalnych udowodniono, że bakteria ta może także porażać komórki człowieka na drodze genetycznej transformacji, co uznano za dowód pomocny w lepszym zrozumieniu horyzontalnego transferu genów (HGT), uważanego przez wielu badaczy za główny czynnik ewolucji (LACROIX i współaut. 2006). Większość doniesień na temat agrobakterii jako patogenów człowieka, w tym nie będących patogenami roślin, dotyczy bakteriemii (zakażenie krwi). Stwierdzono, że Agrobacterium radiobacter (nie majaca plazmidu Ti) atakuje m.in. dzieci $z$ obniżoną odpornością, a szczególnie chore na białaczkę, które maja założone cewniki żylne (silikonowe rurki, do których bakterie maja skłonność adhezji) (MANTADAKIS i współaut. 2010). FENNER i współaut. (2019) opisali przypadek zakażenia rogówki przez Rhizobium (Agrobacterium) radiobacter u człowieka noszacego soczewki kontaktowe. Wykryto także chorobę o nazwie posocznica (sepsa) powodowana przez izolat Agrobacterium sp. (bez plazmidu Ti) u starszego pacjenta poddanego sztucznej wentylacji i antybiotykoterapii, w którego surowicy było czterokrotnie więcej przeciwciał niż u zdrowych dawców (FRENEY i współaut. 1985). W kontekście rozważań zdolności chorobotwórczych tej grupy bakterii na uwage zasługuje praca AUJOULAT i współaut. (2015), w której opisano nowy gatunek bakterii wyizolowanej $z$ ryzosfery ciecierzycy. Nazwano ja Rhizobium pusense. Wielolokusowa analiza sekwencji (MLSA) izolatów klinicznych zidentyfikowanych jako Agrobacterium (Rhizobium) radiobacter, w tym szczepów referencyjnych, wykazała, że $R$. pusense należy do tej samej grupy. Uznano więc, że gatunek ten jest głównym patogenem człowieka. Badania nad chorobotwórczością szczepu referencyjnego tego gatunku (NRCPB10 ${ }^{\mathrm{T}}$ ) wykazały jednak brak zdolności do tworzenia narośli na ciecierzycy i tytoniu (PANDAY i współaut. 2011).

Wśród niektórych gatunków bakterii rodzaju Burkholderia, zidentyfikowano szczepy zakażajace rośliny, zwierzęta i ludzi. Zgrupowano je w „taksonie” B. cepacia complex obejmujacym ponad 20 gatunków charakteryzujacych się różnorodnościa metaboliczna, umożliwiajacca im adaptację do różnych środowisk (DEPOORTER i współaut. 2016). Fitopatogeny powoduja głównie zgnilizny, m.in. bakteriozę cebuli - chorobę objawiająca się gniciem cebul w przechowalniach i w czasie transportu oraz w obrocie handlowym (SOBICZEWSKI i SCHOLLENBERGER 2002). W latach osiemdziesiątych ub. wieku stwierdzono, że B. cepacia spowodowała zakażenia płuc u pacjentów $z$ mukowiscydozą, co może prowadzić do przyspieszonego pogorszenia czynności płuc (tzw. „zespół cepacji”), a nawet przedwczesnej śmierci (MAHENTHIRALINGAM i współaut. 2005).

Sa także doniesienia, że pewne szczepy fitopatogennych gatunków B. gladioli i $B$. glumae, powodowały zakażenia płuc u pacjentów $z$ posocznica spowodowana przez $B$. cenocepacia (SPRINGMAN i współaut. 2009). Badacze podkreślaja mało jeszcze rozpoznane genetyczne zróżnicowanie między patogenami rodzaju Burkholderia powodujacymi choroby roślin i ludzi. Ze względu na zdolności chorobotwórcze tych bakterii podjęto prace nad rozróżnieniem szczepów patogennych od niepatogennych w oparciu o metode MLSA i analizę ich genomów. Na podstawie uzyskanych wyników rozważany jest podział bakterii rodzaju Burkholderia na co najmniej dwa duże klastry, w tym obejmujace patogeny roślin lub zwierzat i człowieka oraz klaster obejmujacy gatunki towarzyszace tylko roślinom, niebędące patogenami (BULGARI i współaut. 2019).

$\mathrm{Na}$ uwage zasługuja bakterie rodzaju Pantoea, zwłaszcza gatunku P. agglomerans, uznawanego za powszechnie występującego na roślinach, niepatogennego epi- i endobionta, ale także okolicznościowego patogenu roślin, zwierząt i ludzi (DUTKIEWICZ i współaut. 2016). Po raz pierwszy stwierdzono, że bakteria ta jest sprawca chorób roślin, na podstawie badań etiologicznych zamierania łodyg i liści cebuli obserwowanego na plantacji nasiennej w Republice Południowej Afryki. Następnie wykazano, że P. agglomerans powoduje więdnięcie i zamieranie liści oraz zgniliznę cebul w Stanach Zjednoczonych, a także zamieranie liści i więdnięcie roślin sorgo i kukurydzy w Meksyku. Ponadto w kilku krajach wykryto nekrozy, uwodnione plamy i/lub zgnilizny różnych organów nadziemnej części roślin, m.in. bawełny, traw i groszku nadmorskiego. Niektóre patowary i szczepy $P$. agglomerans powodują powstawanie narośli m.in. na gipsówce (łyszczec), glicynii i żurawinie. Bakteria ta wykazuje również zdolność tworzenia (w temperaturze otoczenia bliskiej $0^{\circ} \mathrm{C}$ ) ośrodków krystalizacji lodu na roślinach, powodujących uszkodzenia, a nawet zamieranie całych roślin, co prowadzi do znacznych strat gospodarczych. W warunkach naturalnych synergizm omawianej bakterii $z$ mrozem stwierdzono w uprawach kukurydzy, 
ryżu i herbaty. Pewne szczepy $P$. agglomerans występuja $\mathrm{w}$ przyrodzie jako symbionty owadów i innych stawonogów (DUTKIEwICZ i współaut. 2016), które moga być także ich wektorami. Ostatnio udowodniono, że wciornastek tytoniowiec (Thrips tabaci), powodujacy szkody w uprawach cebuli jest także wektorem $P$. agglomerans. Ochrona upraw tej rośliny przed wymienionym szkodnikiem skutkowała zmniejszeniem nasilenia bakteryjnego zamierania liści i zgnilizny cebuli (GRODE i współaut. 2019).

Pantoea agglomerans jest również okolicznościowym patogenem człowieka, a do infekcji dochodzi głównie przez zranienia spowodowane m.in. przez kontakt $z$ roślinami tworzacymi ciernie czy kolce. W warunkach szpitalnych zakażeniu ulegaja przeważnie osoby $z$ obniżona odpornościa (DUTKIEWICZ i współaut. 2016). W wyniku zakażenia moga wystapić zapalenia stawów lub błony maziowej stawów, wnętrza gałki ocznej, okostnej, wsierdzia (błony wyściełającej jamy serca), a także kości i szpiku. Innym ważnym źródłem klinicznego zakażenia przez $P$. agglomerans może być kontakt hospitalizowanych osób $z$ zanieczyszczonym sprzętem medycznym, np. cewnikami dożylnymi lub różnego rodzaju płynami. Niektórzy autorzy uważaja, że chociaż infekcje ludzi przez tę bakterię sa rzadkie, to jednak moga one powodować choroby o groźnym przebiegu, a nawet śmiertelność, zwłaszcza u młodych pacjentów $z$ chorobami wspólistniejącymi. Również zapalenie płuc, zwłaszcza u dzieci, wywołane przez $P$. agglomerans może zagrażać ich życiu.

W wielu rejonach uprawy kukurydzy w Chinach wykryto wierzchołkowa zgniliznę kukurydzy (ang. top rot disease) powodowana przez bakterię Klebsiella pneumoniae, dobrze znanego okolicznościowego sprawcę zapalenia płuc, chorób układu moczowego ludzi i zwierzat, występującego niekiedy jako nieszkodliwy endobiont roślin. Na roślinach kukurydzy występowały objawy chlorozy liści oraz ich przerzedzenie, zwijanie się liści, nacięcia brzegów i zgnilizna wierzchołkowa, a na łodygach - zgnilizny, czemu towarzyszył nieprzyjemny zapach. Badania nad patogennościa wyosobnionego $\mathrm{z}$ kukurydzy izolatu KpC4 K. pneumoniae oraz szczepu klinicznego Kp138, spełniajace postulaty Kocha, potwierdziły jego zdolności chorobotwórcze wobec kukurydzy i myszy. Jedna ze strategii przetrwania tego patogenu jest adaptacja ekologiczna. Stwierdzono na przykład, że K. pneumoniae może bardzo dobrze przeżyć przez co najmniej 6 miesięcy nie tylko w liściach kukurydzy w warunkach naturalnych, ale także w suchych resztkach roślin kukurydzy (HUANG i współaut. 2020). Udo- wodniono także, że szczep Borkar $K$. pneumoniae blokuje system oddychania korzeni roślin $z$ rodzaju Solanaceae stwarzając warunki beztlenowe i produkujac wokół korzeni alkohol wydzielajacy nieprzyjemny zapach, co skutkuje więdnięciem i w końcu zamieraniem roślin (AJAYASREE i BORKAR 2018). Kukurydza może stanowić więc rezerwuar $K$. pneumoniae, a przedstawione wyniki należy traktować jako ostrzeżenie przed potencjalnie niebezpiecznym, okolicznościowym patogenem bakteryjnym, wykazujacym zdolność infekcji zarówno roślin, jak i zwierzat oraz ludzi. W kontekście szkodliwości tego patogenu dla upraw kukurydzy istnieje konieczność prowadzenia badań nad patogeneza i epidemiologia choroby oraz opracowania strategii ochrony tej rośliny. Również w Chinach, na podstawie testu patogeniczności i szerokich badań $z$ zastosowaniem testów fenotypowych i wielolokusowej analizy sekwencji kilku genów metabolizmu podstawowego (MLSA) wykazano, że K. pneumoniae powodowała zgniliznę cebuli (LIU i wspólaut. 2015). Ostatnio dr M. Kałużna $z$ Instytutu Ogrodnictwa-PIB w Skierniewicach stosujac techniki molekularne i test patogeniczności udowodniła, że bakterie rodzaju Klebsiella, w tym $K$. variicola i $K$. oxytoca (zaliczane do patogenów człowieka), powoduja szklista zgniliznę cebuli (dane niepublikowane).

W grupie bakterii wywołujacych choroby człowieka na szczególna uwage zasługuje gatunek Pseudomonas aeruginosa, prawdopodobnie najbardziej rozpowszechniony spośród wszystkich gatunków bakterii. Bakterie te wyizolowano $\mathrm{z}$ różnych środowisk, m.in. $z$ gleby, wody, a także na warunków klinicznych. Badania GREEN i współaut. (1974) wykazały, że $P$. aeruginosa wykrywano w $24 \%$ próbek gleby, ale tylko w $0,13 \%$ próbek roślin warzywnych uprawianych w Kalifornii. Analiza wyosobnionych izolatów, na podstawie ich zdolności do wytwarzania piocyny (bakteriotoksyny), wykazała podobieństwo wielu $z$ nich do szczepów klinicznych. Jednocześnie uznano, że gleba może być rezerwuarem tych bakterii i że maja one potencjał kolonizacji roślin w sprzyjających warunkach temperaturowych i wilgotnościowych. Natomiast w glebach Francji i Burkina Faso (Afryka Zachodnia), niezależnie od ich składu fizyko-chemicznego i klimatu, $P$. aeruginosa występowała bardzo rzadko (DEREDJIAN i współaut. 2014). SHANMUGAM i współaut. (2016) udowodnili, że w stanie Himachal Pradesh w Indiach bakteria ta powoduje zgniliznę szyjki korzeniowej cantedeskii. Choroba występowała na korzeniach, kłączach i pędach tej rośliny. Natomiast w Australii stwierdzono, że $P$. aeruginosa jest sprawca brazowej zgnilizny cebuli, a do in- 
fekcji może dochodzić w okresie zbioru (COTHER i współaut. 1976). Badania przeprowadzone w Chinach wykazały, że jest to patogen okolicznościowy. Izolaty pochodzace $z$ gnijących cebul były podobne do szczepów wzorcowych $P$. aeruginosa (LMG $1242^{\mathrm{T}} \quad Z$ Belgii; IR07358 $z$ Filipin) w zakresie cech fenotypowych, w tym patogenności i zawartości estrów metylowych kwasów tłuszczowych (HaO i XIE 2006). Również doniesienia z Egiptu potwierdzają chorobotwórczość tej bakterii wobec cebuli. Obok podstawowych cech fenotypowych i analizy sekwencji genu kodującego $16 \mathrm{~S}$ rRNA autorzy zbadali czynniki wirulencji reprezentatywnego szczepu, wskazując na jego zdolności do wytwarzania kompleksu polisacharydów degradujacych ścianę komórkową i błonę cytoplazmatyczna cebuli, a także wysoka aktywność proteaz, lipazy, pektynazy i fosfatazy alkalicznej. Obserwacje pod mikroskopem skaningowym ujawniły również możliwość wytwarzania przez te bakterie biofilmu (ABD-ALLAA i współaut. 2010). Na uwagę zasługuja także szczegółowe badania etiologiczne zgnilizny owoców tindy (Praecitrullus fistulosus), rośliny tropikalnej $z$ rodziny dyniowatych, obejmujace testy fenotypowe, w tym test patogenności, oraz analizę sekwencji genu kodującego $16 \mathrm{~S}$ rRNA bakterii pochodzacych $z$ gnijących owoców. Wykazały one, że sprawca gnicia jest $P$. aeruginosa (MONDAL i współaut. 2012). Choroba jest problemem o znaczeniu gospodarczym w uprawach tindy w Indiach. Jej nasilenie przybiera formę epifitozy zwłaszcza w okresach deszczowych i bardzo goracych. Pojawiają się wtedy liczne, od jasno- do ciemnobrazowych, głębokie, okrąłe, miękkie zgnilizny mięsistych tkanek owoców, a niekiedy towarzyszą im wycieki bakteryjne.

$P$. aeruginosa jest także okolicznościowym patogenem człowieka. Powoduje schorzenia $u$ osób $z$ obniżoną odpornością, w tym przewlekłe zakażenia płuc u pacjentów z mukowiscydoza (RAHME i współaut. 1997). Poznano różne czynniki wirulencji tej bakterii, jak egzotoksynę A, elastaze i fosfolipazę C, a obiektem szczegółowych badań był szczep UCBPP-PA14 pochodzacy $z$ warunków klinicznych, wykazujacy potencjał zakażania zarówno liści rzodkiewnika (Arabidopsis thaliana), jak i skóry myszy. Stwierdzono, że mutacje genów zwiąanych $z$ patogennościa tego szczepu (tox $A$, plcS, gacA) powodowały jej osłabienie w stosunku do obu testowanych organizmów, co sugeruje możliwość wspólnego lub podobnego mechanizmu ich zakażania (RAHME i współaut. 1997). Badania przeprowadzone jeszcze w latach 70. ub. stulecia, obejmujace liczne izolaty $P$. aeruginosa pochodzace $\mathrm{z}$ różnych środowisk, w tym $z$ roślin i warunków klinicznych, wykazały ich zdolności chorobotwórcze w stosunku do sałaty (Lactuca sativa 'Great Lakes'), selera (Apium graveolens 'Dulce'), ziemniaka (Solanum tuberosum 'Whiterose'), a także pomidora (Lycopersicon esculentum), ogórka (Cucumis sativus), brukwi (Brassica napobrassica) i marchwi (Daucus carota). Pomimo że udowodniono znaczne zróżnicowanie badanych izolatów w powodowaniu zgnilizn, to jednak nie zaobserwowano różnic między izolatami pochodzacymi $z$ warunków klinicznych oraz pól uprawnych, wody i gleby (SCHROTH i współaut. 2018). Na podkreślenie zasługuje jednak fakt, że dwa izolaty kliniczne (PA13 i PA14) wykazały największą wirulencje $\mathrm{w}$ powodowaniu zgnilizn na wszystkich testowanych roślinach. Badania WALKERA i współaut. (2004) dowiodły, że P. aeruginosa może tworzyć w różnych warunkach biofilm, a cecha ta umożliwia przeżycie bakteriom u chorych osób, nawet po uporczywym leczeniu antybiotykami. Wspomniany szczep PA14 wywoływał zgnilizny korzeni, nie tylko rzodkiewnika pospolitego, ale także bazylii pospolitej (Ocimum basilicum), co skutkowało zamieraniem tych roślin w ciagu siedmiu dni po inokulacji.

\section{KONTAMINACJA ROŚLIN I GLEBY PRZEZ PATOGENY CZŁOWIEKA}

Środowisko roślin może być także nisza wyłącznych patogenów człowieka, powodujących przeważnie choroby u ludzi osłabionych lub ze zmniejszona odpornościa na stresy pochodzenia biotycznego i abiotycznego. Patogeny takie wykryto w ryzosferze i na różnych organach nadziemnej części roślin (TYler i TRIPletT 2008, KIRZINGER i współaut. 2011). Doniesienia ostatnich lat wskazuja na wzrost zachorowań ludzi wskutek spożywania świeżych, nie przetworzonych produktów żywnościowych pochodzenia roślinnego, zwłaszcza owoców i warzyw (LIM i współaut. 2014, SzCZECH i współaut. 2014, AlEGBElEye i współaut. 2018). Wśród możliwości kontaminacji roślin i produktów roślinnych przez bakteryjne patogeny człowieka wymienia się wodę stosowana do nawadniania upraw, glebę lub bezpośredni kontakt $z$ bakteriami. Woda jest uważana za jedno $z$ najważniejszych źródeł zanieczyszczeń, które pochodza m.in. $z$ pobliskich pastwisk, a także po obróbce pozbiorczej owoców i warzyw (AlEGBELEYE i współaut. 2018). Użycie wody niedokładnie odkażonej w chłodnicach wodnych, stosowanej w przechowalnictwie i przetwórstwie świeżych produktów, może spowodować zanieczyszczenie ich całej partii. Ponadto owoce opadłe na zanieczyszczoną glebę oraz świeżo pokrojone warzywa, do 
których bakterie, zwłaszcza rodzaju Salmonella, wykazuja specyficzny tropizm, moga być także przyczyna zatruć. Przenosicielami bakterii sa dzikie zwierzęta, które przebywajacc nawet przez krótki czas na polach maja bezpośredni kontakt $z$ uprawianymi tam roślinami (LIM i współaut. 2014). Również nawozy organiczne, jak nieprzekompostowany obornik czy gnojówka, moga zawierać szkodliwe bakterie. W celu redukcji takich zanieczyszczeń wprowadzono w Stanach Zjednoczonych wymóg stosowania 120 dniowego odstępu między przygotowaniem a wprowadzeniem obornika do gleby (ALEGBELEYE i współaut. 2018). Rośliny moga być zanieczyszczane bakteryjnymi patogenami człowieka w różnych fazach wzrostu, a także podczas zbioru płodów, ich dystrybucji i obrotu handlowego. Warto dodać, że bakterie Listeria monocytogenes, sprawce listeriozy, groźnej choroby $u$ osób $z$ ograniczoną odpornościa, wykryto w próbkach pobranych $z$ klamek drzwi, podłóg czy ścian przechowalni owoców i warzyw. Podobne wyniki uzyskano $z$ badań nad Salmonella enterica - bakteria będaca przyczyna ostrych zatruć pokarmowych, która tworzy biofilm nawet na nierdzewnych powierzchniach metalowych, przez co jest też odporna na dezynfekcje (GAlié i współaut. 2018). W Stanach Zjednoczonych stwierdza się rocznie około 5000 przypadków śmiertelnych zwiazanych $z \quad z a-$ nieczyszczona mikrobiologicznie żywnością, a około 300000 osób jest hospitalizowanych. Jednocześnie oceniono, że choroby pochodzace od takiej żywności powoduja straty wynoszace około $7 \mathrm{mld}$ dolarów rocznie (HUSSAIN i DAwSON 2013). Należy podkreślić, że bakterie $S$. enterica i $L$. monocytogenes należą do najczęściej wymienianych w USA sprawców zachorowań pacjentów spożywających zanieczyszczoną żywność pochodzenia roślinnego (HOFMANN i współaut. 2014). Wiele patogenów jelitowych zwiazanych $z$ żywnościa może przeżywać w glebie nawet przez okres całego roku. Ich występowanie przekłada się bezpośrednio na zanieczyszczenie korzeni, a następnie część nadziemna roślin. I tak, bakteria $E$. coli wchodzaca w skład mikrobiomu jelita grubego człowieka, a także przewodu pokarmowego zwierząt stałocieplnych, m.in. ptaków, bydła, jeleni, psów, owiec czy świń, może przedostawać się do gleby $z$ odchodami, a o jej przeżywalności decyduja takie czynniki jak: skład mechaniczny gleby, występowanie resztek roślinnych i innych mikroorganizmów oraz wilgotność i temperatura (LIM i współaut. 2014). W temperaturze poniżej $25^{\circ} \mathrm{C}$ i wysokiej wilgotności E. coli może przeżyć w glebie nawet 80 dni (CoOLs i współaut. 2001). Po okresie adaptacji bakterie wytwarzaja nitkowate struktury umożliwiajace adhezję do powierzchni roślin, co stwierdzono w przypadku kontaminacji sałaty i rzodkiewki. Wykazano, że serotyp E. coli O157:H7 może wnikać do apoplastu sałaty i szpinaku przez korzenie i liście oraz żyć w nich przez ponad 20 dni (WRIGHT i współaut. 2017). Niektóre szczepy E. coli, produkujące egzotoksynę, powoduja zatrucia pokarmowe u ludzi. Przebieg schorzeń jest różny, niekiedy może być ostry, jednak najczęściej nie jest groźny. Szczególnie niebezpieczny jest serotyp $E$. coli zawierajacy werotoksynę (VTEC), mogacy doprowadzić do zespołu hemolityczo-mocznicowego i uszkodzenia centralnego układu nerwowego (KAPER i współaut. 2004). Do powszechnie występujacych w glebach użytkowanych rolniczo należa bakterie rodzaju Salmonella, przy czym obornik jest uznawany za główne źródło zanieczyszczeń. Udowodniono, że bakterie te lepiej przeżywaja w glebie $Z$ dodatkiem kompostu pochodzacego $Z$ obornika drobiowego niż obornika bydlęcego. Bakterie serotypu Typhimurium S. enterica przeżywały w glebie $z$ dodatkiem różnych kompostów przez okres od 203 do 231 dni. Wykrywano je także w roślinach rzodkiewki nawet przez 84 dni, a w roślinach marchwi przez 203 dni od wysiania nasion (ISLAM i współaut. 2004). Bakterie te rozprzestrzeniaja się $\mathrm{w}$ roztworze glebowym nawet przy braku nawożenia. Wykazano również, że $S$. enterica ma wysoka zdolność kolonizacji zarówno epidermy, jak i tkanek wewnętrznych różnych roślin oraz jest przyczyna częstych chorób zakaźnych, przebiegających najczęściej w postaci ostrych zatruć pokarmowych. Inna bakterie, Campylobacter jejuni, powodujaca ostre zapalenie żoładka i jelit, które może mieć ostry przebieg zwiąany $z$ powstawaniem wrzodów, izolowano $z$ korzeni rzodkiewki i rizosfery szpinaku, odpowiednio przez 23 i 28 dni od wprowadzenia do gleby, a rośliny utrzymywano $\mathrm{w}$ temperaturze $10^{\circ} \mathrm{C}$. Jako bakteria ciepłolubna przeżywała w rizosferze szpinaku przez dłuższy okres w temperaturze $16^{\circ} \mathrm{C}$, co wskazuje na jej zdolność adaptacji i kontaminacji środowiska, skutkujacca przypadkami zanieczyszczeń żywności pochodzenia roślinnego. Składniki gleby moga więc stanowić mikronisze ekologiczne dla bakterii dostarczajac im substancji pokarmowych uwalnianych $z$ materii organicznej (LIM i współaut. 2014). Różne patogeny jelitowe, w tym $S$. enterica, L. monocytogenes, E. coli, Shigella spp., Campylobacter spp., Yersinia spp. i Staphylococcus aerus, izolowano ze świeżych owoców i warzyw. Zanieczyszczenie owoców, kwiatów czy pędów tymi bakteriami prowadziło do kolonizacji przez nie także wewnętrznych tkanek roślin. I chociaż nie sa one zwykle uważa- 
ne za składniki populacji mikroorganizmów zasiedlajacych fyllosferę (nadziemna część roślin wraz $z$ mikrobiomem i mikrofauna występujacca na ich powierzchni), to jednak stwierdzane przypadki zakażeń ludzi wskazują na celowość rewizji tego poglądu (LIM i współaut. 2014). Bakterie jelitowe moga się także przemieszczać w tkankach przewodzacych roślin, np. z korzeni do liści i owoców. E. coli lub S. typhimurium wykryto na powierzchni zdezynfekowanych liści sałaty uprawianej w pożywkach wodnych (system hydroponiczny, uprawa bezglebowa) lub w glebie, zanieczyszczonych tymi bakteriami. S. typhimurium dodana do wody stosowanej do nawadniania pietruszki rozprzestrzeniała się $z$ korzeni do liści i pędów. Warto podkreślić, że mutant tej bakterii, pozbawiony genów kodujących syntezę celulozy i adhezyny, przemieszczał się do liści w znacznie mniejszym stopniu niż szczepy dzikie. Na przeżywalność patogenów jelitowych w fyllosferze roślin wpływaja m.in. poziom odżywienia roślin, promieniowanie UV, substancje toksyczne wydzielane przez rośliny oraz warunki wilgotnościowe, zwłaszcza susza (LIM i współaut. 2014). Bakterie E. coli O157:H7 przeżywały na sałacie przez ponad $20 \mathrm{dni}$, ale na długość tego okresu wpływał wiek roślin. Liczebność bakterii była większa, kiedy rośliny nawadniano systemem typu deszczownianego w porównaniu do kroplowego. Tworzenie biofilmu na roślinach przez te patogeny sprzyja ich przeżywaniu.

\section{BAKTERIE JAKO CZYNNIKI BIOLOGICZNEJ OCHRONY ROŚLIN PRZED CHOROBAMI}

W środowisku roślin występuja również bakterie korzystnie oddziałujace na ich zdrowotność, wzrost i plonowanie. Bakterie takie dysponuja mechanizmami, które umożliwiaja bezpośrednie i/lub pośrednie ograniczanie sprawców chorób, wykazujac wobec nich aktywność antagonistyczna, a możliwie także indukując odporność roślin na porażenie (SoBICZEWSKI 2009). Antagonizm bakterii wobec patogenów obejmuje trzy główne rodzaje interakcji: antybiozę, współzawodnictwo o pokarm i miejsce oraz pasożytnictwo. Natomiast efektem indukcji odporności jest stymulacja reakcji obronnych rośliny, skutkujaca wytwarzaniem m.in. reaktywnych form tlenu, fitoaleksyn, związków fenolowych, białek zwiazanych $z$ patogeneza (PR-proteins) czy powstawaniem fizycznych barier, np. w epidermie. Zdolność produkcji antybiotycznych metabolitów, często o szerokim spektrum działania, wykryto u bakterii rodzajów Agrobacterium, Bacillus, Pantoea, Pseudomonas, Serratia, Stenotrophomonas, Streptomy- ces, których szczepy różnych gatunków wykazuja potencjał ochrony roślin przed chorobami. W niektórych relacjach między patogenami a pożytecznymi bakteriami, szczególnie ważne jest współzawodnictwo o pokarm i miejsce. Przykładem moga tu być owoce atakowane przez tzw. patogeny przyranne np. Penicillium expansum, sprawce mokrej zgnilizny jabłek. W zranieniach uwalniaja się substancje pokarmowe atrakcyjne zarówno dla patogenu, jak i antagonisty, który jednak wykorzystujac je szybciej zapobiega infekcji i rozwojowi choroby. Najczęściej bakterie takie maja szeroki zakres gospodarzy, a przez to przewagę w konkurencyjnej zdolności przystosowania się do różnych warunków środowiskowych. Z drugiej strony, co również istotne, ryzyko powstania odporności patogenów na atak antagonisty jest bardzo niskie. Natomiast bakterie wykazujace zdolność pasożytnictwa w stosunku do potencjalnego patogenu charakteryzują się wąskim zakresem gospodarzy, a ich aktywność zależy od warunków środowiskowych, w tym głównie decydujących o możliwości wzrostu i rozmnażania. Proces wytwarzania enzymów litycznych jest tu regulowany na drodze sygnałów pochodzacych od patogenu, co oznacza, że sa one specyficzne i zależne od substratu.

Interakcje między pożytecznymi bakteriami a patogenami sa wysoce regulowanymi kaskadami zjawisk metabolicznych, często łączących różne mechanizmy działania. W tym kontekście na podkreślenie zasługuje fakt, że uczestniczace $\mathrm{w}$ nich związi, takie jak cząsteczki sygnałowe, enzymy i różne metabolity, sa wytwarzane w warunkach naturalnych w niskim stężeniu (KöHL i współaut. 2011). Sytuacja zmienia się jednak, kiedy w celach utylitarnych wprowadza się do środowiska odpowiednio więcej tych bakterii. Ważnymi czynnikami biologicznej ochrony roślin przed chorobami odglebowymi, powodowanymi przez grzyby i legniowce, sa bakterie rodzaju Pseudomonas. Wiele $z$ nich wytwarza enzymy lityczne i substancje antybiotyczne, oraz siderofory - zwiazki chelatowe wiążące jony żelaza trójwartościowego, będącego ważnym składnikiem biogennym wielu mikroorganizmów. Odgrywaja one zasadnicza rolę m.in. w tzw. glebach opornych, nie dopuszczajac do rozwoju bytujacych tam patogenów roślin. Szczepy gatunku Pseudomonas fluorescens, wytwarzające pyrolnitrynę i pioluteorynę, okazały się skutecznymi antagonistami takich glebowych patogenów roślin jak: Rhizoctonia solani, Thielaviopsis basicola, Verticillium dahliae, Alternaria spp. oraz Pythium ultimum i Pectobacterium carotovorum (WELlER 2007). Ponadto różne szczepy Pseudomonas spp. wytwarzajace 2,4-diace- 
tylofloroglucynol (DAPG), antybiotyk o dużej aktywności wobec wielu patogenów roślin, wykazuja także wysoka zdolność kolonizacji systemu korzeniowego i skutecznej konkurencji o pokarm oraz moga indukować $u$ roślin reakcje obronne na stresy pochodzenia biotycznego. Na bazie szczepu A506 P. fluorescens w Stanach Zjednoczonych zarejestrowano preparat BlightBan ${ }^{\circledR A 506}$ przeznaczony do ochrony sadów jabłoniowych przed przymrozkami i zaraza ogniowa, a do ochrony przed chorobami przechowalniczymi owoców drzew ziarnkowych i cytrusów preparaty Bio-Save ${ }^{\circledR}$ 10LP i Bio-Save ${ }^{\circledR}$ 11L, których składnikami czynnymi sa szczepy, odpowiednio ESC-10 i ESC-11 gatunku Pseudomonas syringae (SOBICZEWSKI 2009). Badania BRYK i współaut. (2004) wykazały, że szczepy B194 i B224 Pseudomonas spp. ograniczały, na drodze pasożytnictwa, rozwój Botrytis cinerea i Penicillium expansum, sprawców odpowiednio szarej pleśni i mokrej zgnilizny jabłek. W tej grupie bakterii należy jeszcze wspomnieć o Pseudomonas aeruginosa. Badania przeprowadzone $\mathrm{w}$ Indiach ze szczepem PNA1 tego gatunku, wyizolowanym $z$ ryzosfery ciecierzycy, wykazały ich wysoka skuteczność ochronna przeciwko chorobom powodowanym przez Fusarium oxysporum f.sp. ciceris i Fusarium udum na ciecierzycy (ANJAIAH i współaut. 2003), a badania w Belgii ze szczepem 7NSK - przez Pythium sp. na pomidorach (BUYSENS i współaut. 1996). $\mathrm{Na}$ uwage zasługuje jeszcze biopreparat zawierajacy dziki szczep $P$. aeuruginosa i jego mutanty, opracowany i opatentowany w Stanach Zjednoczonych (patent nr. 5762928) do ochrony grzybów uprawnych przed zielona pleśnia (ang. green mold) powodowana przez Trichoderma harzianum).

Glebę zanieczyszczona patogenami roślin może „leczyć” Agrobacterium radiobacter, bakteria glebowa o zdolnościach antagonistycznych wobec A. tumefaciens - sprawcy guzowatości korzeni, a także ograniczająca inne czynniki związane $z$ choroba replantacji. Choroba ta występuje najczęściej w uprawach sadowniczych po posadzeniu jakiegoś gatunku roślin na stanowisku po tym samym gatunku, np. jabłoni po jabłoniach. A. radiobacter wytwarza bakteriocynę o nazwie agrocyna oraz egzopolisacharydy, które moga indukować wytwarzanie w roślinach fitoaleksyn. Najszersze zastosowanie w praktyce znalazł szczep K84 A. radiobacter, będący składnikiem biopreparatów do ochrony drzew owocowych i krzewów róży przed guzowatościa korzeni. Na bazie tego szczepu Pabianickie Zakłady Farmaceutyczne produkowały preparaty Polagrocyna SL i Polagrocyna PC (SOBICZEWSKI i współaut. 1995, SoBICZEWSKI 2009). Dużą zaletą $A$. radiobacter jest zdolność saprotroficznego przeżywania w ryzosferze roślin, nawet przez kilka lat. Ich obecność w glebie sadu jabłoniowego powodowała wzrost liczebności innych pożytecznych bakterii, w tym niesymbiotycznie wiążących azot. MAZZOLA i FREILICH (2017) sformułowali opinię, że najlepszym sposobem eliminacji chorób odglebowych byłoby wykorzystanie bakterii pożytecznych naturalnie zasiedlających glebę „zmęczona” (której skutkiem jest choroba replantacji), poprzez taka modyfikacje środowiska, aby stymulowało ono ich rozmnażanie i aktywność.

$\mathrm{Na}$ szczególna uwage zasługuje gatunek Pantoea agglomerans, którego niektóre szczepy, wyosobnione i zbadane $\mathrm{w}$ różnych krajach, wykazały wysoka skuteczność przeciwko chorobom roślin powodowanym przez bakterie i grzyby, a zwłaszcza przeciwko zarazie ogniowej jabłoni i grusz (JOHNSON i STOCKWELL 1998, BRAUN-KIEWNICK i wspó1aut. 2000, NUNES współaut. 2002). W niektórych krajach m.in. w Stanach Zjednoczonych i Nowej Zelandii zarejestrowano biopreparaty (Blossom Bless ${ }^{\mathrm{TM}}$, Bloomtime, PomaVita ${ }^{\mathrm{TM}}$ ) na bazie różnych szczepów tej bakterii, ale ich rejestracja w Europie napotyka trudności, ponieważ $P$. agglomerans jest uznawany za okolicznościowy patogen człowieka. W Dyrektywie 2000/54/WE Parlamentu Europejskiego i Rady $z$ dnia 18 września 2000 r. zaklasyfikowano bowiem bakterie „Enterobacter spp." (takson, w skład którego wchodzi $P$. agglomerans) do grupy 2 bezpieczeństwa biologicznego, co oznacza, że moga one wywoływać chorobę u ludzi i moga być niebezpieczne w miejscu pracy. Badania porównawcze szczepów wyizolowanych $z$ roślin oraz warunków klinicznych, ukierunkowane na poszukiwanie różnicujących je markerów genomowych wykazały, że większość szczepów klinicznych jest niewłaściwie zaklasyfikowana do gatunku $P$. agglomerans. Uzyskany wynik oparto na wielolokusowej analizie filogenetycznej i fluorescencyjnym polimorfizmie długości amplifikowanych fragmentów (fAFLP) (REZZONICO i współaut. 2009). Autorzy uważaja, że ma to związek z m.in. wcześniejszymi zmianami w taksonomii kompleksu Enterobacter agglomerans/Erwinia herbicola i jego zgrupowaniem w jednym gatunku $P$. agglomerans. Na podkreślenie zasługuje fakt, że w gatunku tym nie zidentyfikowano odrębnego markera dla szczepów klinicznych i szczepów przeznaczonych do biologicznej ochrony roślin, Przypuszczalny marker fAFLP został wykryty tylko w tej drugiej grupie szczepów i może być przydatny w ich oznaczaniu (selekcji) pod kątem bezpieczeństwa biologicznego. Pomocne może być także zbadanie patogenności szczepów wobec ludzi zgodnie $z$ postulatami 
Kocha, ale jak widać problem jest $i$ to nie tylko w tej grupie bakterii.

Niektóre gatunki bakterii rodzaju Bacillus wytwarzaja lipolisacharydy będace antybiotykami przeciwgrzybowymi, np. ituryny, bacillomycynę, surfaktynę. $\mathrm{Na}$ szczególna uwage zasługuje ituryna A wykazujaca silną aktywność wobec takich patogenów jak: Rhizoctonia solani, Pythium ultimum, Sclerotinia sclerotiorum czy Fusarium oxysporum. Wykazano, że różne szczepy $B$. subtilis (np. EBW4, BACT-1) eliminowały skutki choroby replantacji, stymulowały rozwój systemu korzeniowego i plonowanie jabłoni (SOBICZEWSKI 2009). Na bazie szczepu QST 713 B. subtilis, w kilku krajach europejskich, w tym w Polsce, zarejestrowano biopreparat Serenade ASO, przeznaczony do walki $z$ zaraza ogniowa na jabłoniach i gruszach, rakiem bakteryjnym i brunatna zgnilizna na moreli, brzoskwini, wiśni, czereśni i śliwie, szara pleśnia i maczniakiem prawdziwym na aronii, borówce wysokiej, jeżynie, malinie, żurawinie, porzeczce czarnej i kolorowej oraz agreście, a także przeciwko szarej pleśni i mączniakowi prawdziwemu truskawki i winorośli. Natomiast składnikami czynnymi preparatów Amylo-X WG, Serifel i Taegro sa odpowiednio szczepy D747, MB1600 i FZB 24 bakterii $B$. amyloliquefaciens.

Wiele bakterii reprezentujacych różne rodzaje taksonomiczne wykazuje także zdolność pasożytnictwa, mechanizmu zwiazanego m.in. $z$ wydzielaniem enzymów hydrolitycznych rozkładajacych ścianę komórkowa patogenów, która u wielu $z$ nich jest zbudowana $z$ chityny. Zdolność do wydzielania chitynaz jest uważana za ważny mechanizm działania bakterii rodzajów Bacillus, Vibrio czy Serratia przeciwko różnym patogenom glebowym i nalistnym (SwIONTEK-BRZEZINSKA i współaut. 2014).

Czynnikami biologicznej ochrony roślin przed chorobami moga być również bakterie wchodzace w skład wspomnianego wcześniej kompleksu Burkoholderia cepacia, wytwarzajace substancje antybiotyczne wobec różnych patogenów roślin, w tym glebowych, nalistnych oraz powodujacych choroby przechowalnicze owoców (PARKE 2000).

Podsumowując należy podkreślić, że bakterie należace do tych samych gatunków moga być zarówno patogenami roślin, patogenami człowieka, jak i czynnikami biologicznej ochrony przed chorobami. Co więcej, nawet te same szczepy moga oddziaływać korzystnie na rośliny, a jednocześnie stanowić zagrożenie dla środowiska. Różnice między bakteriami pożytecznymi i szkodliwymi nie sa więc tak jednoznaczne i - co warto zauważyć - wskutek horyzontalnego transferu genów może nastąpić przekazanie między bakteriami cech niekorzystnych, np. zdolności chorobotwórczych. Analiza porównawcza sekwencji genomów wykazała, że bakterie takie maja pewne wspólne struktury genomów, co sugeruje możliwość zmiany ich sposobu życia w konkretnej niszy ekologicznej i nadarzajacym się potencjalnym gospodarzu (Bulgari i współaut. 2019). Z tego punktu widzenia użycie bakterii do walki $z$ patogenami roślin może skutkować nasileniem chorób, a nawet pojawieniem się nowych patogenów. I chociaż ochrona roślin metoda biologiczna jest perspektywa obiecujaca, to ważne jest, aby mieć w polu widzenia jej bezpośredni lub pośredni wpływ na środowisko i zdrowie ludzi. Zastosowanie bakterii w ochronie roślin przed chorobami wymaga więc przeprowadzenia szczegółowych badań i analiz, obejmujących m.in. ich skuteczność, ryzyko wytworzenia odporności i specyfike działania wobec patogenu, fizjologię rośliny, która ma być chroniona, a także analizę możliwości wystapienia niekorzystnych skutków ich stosowania, w tym zagrożeń dla środowiska, a zwłaszcza ludzi (KöHL i współaut. 2011). Pełniejszego wyjaśnienia możliwych interakcji między bakteriami i roślinami, a tym samym ich znaczenia dla agroekosystemów, upatruje się w badaniach $z$ zastosowaniem nowoczesnych technologii "omicznych" (genomika, proteomika lub metabolomika).

\section{Streszczenie}

Spośród poznanych dotychczas ponad 10000 hodowalnych gatunków bakterii, ponad 150 powoduje choroby roślin. Ze względu na ich objawy fitopatogeny bakteryjne dzieli się na nekrogeny, macerogeny i onkogeny. Niektóre $z$ nich wykazują zdolność zakażania organizmów spoza królestwa roślin, w tym człowieka. Poważnym zagrożeniem jest także kontaminacja roślin i gleby przez wyłaczne patogeny człowieka i/lub zwierzat. Sa to głównie bakterie jelitowe. W środowisku roślin występuja również bakterie korzystnie oddziałujące na ich zdrowotność, wzrost i plonowanie. Bakterie takie dysponuja mechanizmami, które umożliwiają bezpośrednie i/lub pośrednie ograniczanie sprawców chorób, wykazując wobec nich aktywność antagonistyczna, a możliwie także indukując odporność roślin na porażenie. Ich zastosowanie w praktyce wymaga jednak przeprowadzenia szczegółowych badań, bowiem nawet te same szczepy moga korzystnie oddziaływać na rośliny, a jednocześnie stanowić różnego rodzaju zagrożenia. I chociaż ochrona roślin metoda biologiczna jest obiecujaca perspektywa, to ważne jest, aby mieć w polu widzenia jej możliwy, bezpośredni lub pośredni, negatywny wpływ na środowisko i zdrowie ludzi.

\section{LITERATURA}

ABD-AllaA M. H., Bashandya S. R. , RATERINGC S., SCHNEL S., 2011. First report of soft rot of onion bulbs in storage caused by Pseudomonas aeruginosa in Egypt. J. Plant Interact. 6, 229-238. 
Agrios G. N., 2005. Plant Pathology. Elsevier Academic Press.

AJAYASREE T. S., BORKAR S. G., 2018. Pathogenic potentiality of the bacterium of Klebsiella pneumoniae strain Borkar on different plants. J. Appl. Biotechnol. Bioeng. 5, 233-235.

Alegbeleye O. O., Singleton I., ANDERSon S. S. A., 2018. Sources and contamination routes of microbial pathogens to fresh produce during field cultivation: A review. Food Microbiol. 73, 177-208.

ANJAiAH V., CORNElis P., KoEdam N., 2003. Effect of genotype and root colonization in biological control of fusarium wilts in pigeonpea and chickpea by Pseudomonas aeruginosa PNA1. Can. J. Microbiol. 49, 2, 85-91.

Aujoulat F., MARCHANDIN H., ZORGNIOTTI I., MASNOU A., JUMAS-BILAK E., 2015. Rhizobium pusense is the main human pathogen in the genus Agrobacterium/ Rhizobium. Clin. Microbiol. Infect. 21, 472.e1-472.e5.

BILling E., 1987. Bacteria as plant pathogens. Asp. Microbiol. 14, 1-79.

Braun-Kiewnick A., Jacobsen B. J., Sands D. C., 2000. Biological control of Pseudomonas syringae pv. syringae, the causal agent of basal kernel blight of barley, by antagonistic Pantoea agglomerans. Phytopathology 90, 368375.

BRYK H., DYKI B., SOBICZEWSKI P., 2004. Inhibitory effect of Pseudomonas spp. on the development of Botrytis cinerea and Penicillium expansum. Plant Protect. Sci. 40, 128-134.

Buysens S., Heungens K., POPPE J., HofTe M., 1996. Involvement of pyochelin and pyoverdin in suppression of Pythium-Induced Damping-Off of tomato by Pseudomonas aeruginosa 7NSK2. Appl. Environ. Microbiol. 62, 865871.

Bulgari D., Montagna M., GobBi E., FAoro F., 2019. Green technology: bacteria-based approach could lead to unsuspected microbe-plant-animal interactions. Microorganisms 7, doi:10.3390/microorganisms7020044.

COOLS D., MERCKX R., VlassaK K., VERHAEGEN J., 2001. Survival of E. coli and Enterococcus spp. derived from pig slurry in soils of different texture. Appl. Soil Ecol. 17, 53-62.

COTHER E. J., DARBYSHIRE B., BREWER J., 1976. Pseudomonas aeruginosa: cause of internal brown rot of onion. Phytopathology 66, 828834.

Depoorter E., Bull M. J., Peeters C., Coenye T. VANDAMME P., MAHENTHIRALINGAM E., 2016. Burkholderia: an update on taxonomy and biotechnological potential as antibiotic producers. Appl. Microbiol. Biotechnol. 100, 5215-5229.

DeredJian A., COLINON C., Hien C., BROTHIER E., YOUENOU B., COURNOYER B., DEQUIEDT S., HARTMANN A., JOLIVET C., HOUOT S., RANJARD L., SABY N. P. A., NAZARET S., 2014. Low occurrence of Pseudomonas aeruginosa in agricultural soils with and without organic amendment. Front. Cell. Infect. Microbiol. 4, 1-12.

DutKIEWICZ J., MACKIEWICZ B., LemieszeK M. K., Golec M., Milanowski J., 2016. Pantoea agglomerans: a mysterious bacterium of evil and good. Part III. Deleterious effects: infections of humans, animals and plants. Ann. Agricult. Environ. Med. 23, 197-205.

FEnNER B. J., Kumara A., TANA N. Y. Q., ANGA M., 2019. Case of isolated Rhizobium radiobacter contact lens-related infectious keratitis: A plant microbe now emerging as a human pathogen. Am. J. Opthal. Case Rep. 15, doi: 10.1016/j.ajoc.2019.100476.
FRENEY J., GRUER L. D., BORNSTEIN N., KIREDJIAn M., Guilvout I., Letouzey M. N., Combe C., Fleurette J., 1985. Septicemia caused by Agrobacterium sp. J. Clin. Microbiol. 22, 683685.

Galié S., García-Gutiérrez C., Miguélez E. M., VILLAR C. J., LOMBÓ F., 2018. Biofilms in the food industry: Health Aspects and Control Methods. Front. Microbiol. 9, doi: 10.3389/ fmicb.2018.00898.

Green S. K., Schroth M. N., CHO J. J., Kominos S. D., VITANZA-JACK V. B., 1974. Agricultural plants and soil as a reservoir for Pseudomonas aeruginosa. Appl. Microbiol. 28, 987-991.

GRODE A. S., BRISCO-MCCANN E., WIRIYAJITSONBOOM P., HaUSBECK M. K., SZENDREI Z., 2019. Managing onion thrips can limit bacterial stalk and leaf necrosis in Michigan onion fields. Plant Disease 103, 938-943.

HAO X. J., XIE G. L., 2006. Internal brown rot of onion caused by an opportunistic bacterial pathogen (Pseudomonas aeruginosa) in China. J. Plant Pathol. 88, 342.

Hofmann A., Fischer D., HaRTMANn A., Schmid A., 2014. Colonization of plants by human pathogenic bacteria in the course of organic vegetable production. Front. Microbiol. Plant-Microbe Interacti. 5, 1-11.

Huang M., Pengfei H. E., Shahzad M., Yixin W. U., Xingyu L., Pengbo H., YueqIU H., 2020. Ecology and etiology of bacterial top rot in maize caused by Klebsiella pneumoniae KpC4. Microb. Pathogen. 139, doi.org/10.1016/j. micpath.2019.103906.

Hussain M. A., DAWSON C. O., 2013. Economic impact of food safety outbreaks on food businesses. Foods 2, 585-589.

Islam M., Morgan J., DOYle M. P., Phatak S. C., MillNER P., JiANG X., 2004. Fate of Salmonella enterica serovar Typhimurium on carrots and radishes grown in fields treated with contaminated manure composts or irrigation water. Appl. Environ. Microbiol. 70, 2497-2502.

JANSE J. D. 2005. Phythobacteriology. CABI Publishing.

Johnson K. B., STOCKWEll V. O., 2000. Biological control of fire blight. [W:] Fire blight, the disease and its causal agent, Erwinia amylovora. VANNESTE J. L. (red.). CABI Publishing, 319-338

KADO C. I., 2010. Plant Bacteriology, APS Press, St. Paul, Minnesota, USA.

KAMIŃSKA M., 2004. Choroby roślin ogrodniczych powodowane przez fitoplazmy. Hortpress, Sp. $z$ o.o., Warszawa.

KAPER J. B., NATARO J. P., Mobley H. L., 2004. Pathogenic Escherichia coli. Nat. Rev. Microbiol. $2,123-140$.

KIM J.-S., YOON S.-J., PARK Y.-J., KIM S.-Y., RYU C.-M., 2020. Crossing the kingdom border: human diseases caused by plant pathogens. Environ. Microbiol. 22, 2485-2495.

Kirzinger M. W. B., NADARASAH G., STAVRINIDES J., 2011. Insights into cross-kingdom plant pathogenic bacteria. Genes 2, 980-997.

KÖHL J., KOLNAAR R., RAVENSBERG W. J., 2019. Mode of action of microbial biological control agents against plant diseases: relevance beyond efficacy. Front. Plant Sci. 10, doi. org/10.3389/fpls.2019.00845

LacroIX B., TZFIRA T., VAinsteIN A., Citovsky V., 2006. A case of promiscuity: Agrobacterium's endless hunt for new partners. Trends Genet. 22, 29-37. 
LIM J.-A., LEE D. H., HEU S., 2014. The interaction of human enteric pathogens with plants. Plant Pathol. J. 30, 109-116.

LIU S., LV M., GU Y., ZHOU J., 2015. First report of bulb disease of onion caused by Klebsiel la pneumonia in China. Plant Disease 99, doi. org/10.1094/PDIS-05-15-0513-PDN.

MAHENTHIRALINGAM E., URBAN T. A., GOLDBERG J. B., 2005. The multifarious, multireplicon Burkholderia cepacia complex. Nat. Rev. Microbiol. 3, 144-156.

MANTADAKIS E., Kondi A., Christidou A., Kalmanti M., 2010. Agrobacterium radiobacter bacteremia in a child with acute lymphoblastic leukemia. World J. Pediatr. 6, 81-184.

Mazzola M., FREILICH S., 2016. Prospects for soil borne disease control: application of indigenous versus synthetic microbiome. Phytopathology 107, 256-263.

Mondal K. K., MANi C., Singh J., DAVE S., Tipre D. R., Kumar A., Trivedi., 2012. Fruit rot of tinda caused by Pseudomonas aeruginosa - a new report from India. Plant Disease 96, doi: 10.1094/PDIS-05-11-0404.

Nunes C., Usall J., TeiXido N., Fons E., Vinas I., 2002. Post-harvest biological control by Pantoea agglomerans (CPA-2) on Golden Delicious apples. J. Appl. Microbiol. 92, 247-255.

PANDAY D., SCHUMANN P., DAS K., 2011. Rhizobium pusense sp. nov., isolated from the rhizosphere of chickpea (Cicer arietinum L.). Int. J. Syst. Evol. Microbiol. 61, 2632-2639.

Paphitou N. I., ROLSTON K. V., 2003. Catheter-related bacteremia caused by Agrobacterium radiobacter in a cancer patient: Case report and literature review. Infection 31, 421-424.

PARKE J. L., 2000. Burkholderia cepacia: Friend or Foe? Plant Health Instructor, doi: 10.1094/ PHI-I-2000-0926-01.

Rahme L. G., TAN M.-W., LE L., WONG S. M., Tompkins R. G., CALDERWOOD S. B., Ausubel F. M., 1997. Use of model plant hosts to identify Pseudomonas aeruginosa virulence factors. Proc. Natl. Acad. Sci. USA 94, 13245-13250.

Rezzonico F., SMits T. H. M., Montesinos E., FREY J. E., DUFFY B., 2009. Genotypic comparison of Pantoea agglomerans plant and clinical strains. BMC Microbiol. 9, doi:10.1186/14712180-9-204.

ShanMUgam V., ThaKur H., PaUl S., Bhadwal P., MAHAJAN S., KUMAR MONDAL K., 2016. First report of collar rot caused by Pseudomonas aeruginosa on calla lily (Zantedeschia elliottiana). Phytopathologia Mediterranea 55, 427431.

Schroth M. N., Cho J. J., GReen S. K., Kominos S. D., 2018. Epidemiology of Pseudomonas aeruginosa in agricultural areas. J. Med. Microbiol. 67, 1191-1201.

SoBICZEWSKI P., 1999. Guzowatość korzeni (Agrobacterium tumefaciens) - ważna nowotworowa choroba roślin sadowniczych. Post. Nauk Rol. 5, 17-30.

SOBICZEWSKI P., 2009. Bakterie wykorzystywane $w$ produkcji roślinnej. [W:] Biotechnologia roślin. MALEPSZY S. (red). PWN Warszawa, 172213.

Sobiczewski P., ScHOlLEBERGER M., 2002. Bakteryjne choroby roślin ogrodniczych. PWRiL, Warszawa.

SOBICZEWSKI P., BERCZYŃSKI S., CIECHANOWSKA M., KARCZEWSKI J., ŁUBISZ K., MAJDZIAK K., SZCZEPANIAK J., FILIP A., SEDlACZEK L., 1995. Sposób wytwarzania biopreparatu do ochrony korzeni podkładek drzew owocowych $i$ róży przed guzowatościa korzeni. Patent nr 167547.

Springman A. C., Jacobs J. L., Somvanshi V. S., SundiN G. W., MULKS M. H., WhitTAM T. S., VisWANATHAN P., GRAY L. P., LIPUMA J. J., CICHE T. A., 2009. Genetic diversity and multihost pathogenicity of clinical and environmental strains of Burkholderia cenocepacia. Appl. Environ. Microbiol. 75, 5250-5260.

SWIONTEK-BRZEZINSKA M., JANKIEWICZ U., BURKOWSKA A., WALCZAK M., 2014. Chitinolytic microorganisms and their possible application in environmental protection. Curr. Microbiol. 68, 71-81.

SzCZeCH M., SMOlińsKa U., Kowalska B., Kosson R., SZWEJDA-GRZYBOWSKA J., TUSZYŃSKA M., 2014. Zdrowa żywność: mikrobiologiczne bezpieczeństwo $w$ produkcji rolniczej. Broszura Instytutu Ogrodnictwa w Skierniewicach,

TYleR H. L., TRIPLETT E. W., 2008. Plants as a habitat for beneficial and/or human pathogenic bacteria. Annu. Rev. Phytopathol. 46, 5373.

WAlker T. S., BAIS H. P., DE'ZIEl E., SchWEIZER H. P., RAHME L. G., Fall R., Vivanco J. M., 2004. Pseudomonas aeruginosa-plant root interactions. Pathogenicity, biofilm formation, and root exudation. Plant Physiol. 134, 320331.

WELlER D. M., 2007. Biological control of soilborne plant pathogens. Annu. Rev. Phytopatol. 26, 379-407.

Wright K. M., Crozier L., Marshall J., Merget B., Holmes A., Holden N. J., 2017. Differences in internalization and growth of Escherichia coli O157:H7 within the apoplast of edible plants, spinach and lettuce, compared with the model species Nicotiana benthamiana. Microb. Biotechnol. 10, 555-569. 
KOSMOS Vol. 70, 4, 685-696, 2021

\section{PIOTR SOBICZEWSKI}

The National Institute of Horticultural Research, 1/3 Konstytucji 3 maja Str., 96-100 Skierniewice, E-mail: Piotr.Sobiczewski@inhort.pl

BACTERIA IN THE PLANT ENVIRONMENT - ENEMIES AND ALLIES

\section{Summary}

Of the more than 10000 cultivable species of bacteria known so far, more than 150 cause plant diseases. Due to their symptoms, bacterial phytopathogens are divided into necrogens, macerogens and oncogenes. Some of them are capable of infecting organisms outside the plant kingdom, including humans. Contamination of plants and soil by only human and/or animal pathogens is also a serious threat. They are mainly intestinal bacteria. There are also bacteria in the plant environment that have a beneficial effect on their health, growth and yield. Such bacteria have mechanisms that allow the direct and/ or indirect control of disease agents showing antagonistic activity towards them and possibly inducing plant resistance to infection. Their use in practice, however, requires detailed research, because even the same strains can have a beneficial effect on plants and at the same time pose various types of threats. Although biological plant protection is a promising prospect, it is important to have possible direct or indirect negative effects on the environment and human health in the field of vision.

Key words: Phytopathogens, pathogens of plants and human, contamination, beneficial bacteria 